red. The nasal fossa on the affected side was not encroached apon. There was a little depression of the palate on that side, but so slight was it that it was scarcely noticeable. The cheek was, on careful comparison, found to be perhaps a little raised. The orbit was not affected. On the day after admission I removed the second bicuspid tooth. With it came away a piece of what was evidently sareoma tissue. There was a little bleeding. The alveolar walls were found to be separated by a soft new growth which extended upwards into a distended antrum. On May 31st, the patient being under chloroform, I removed the superior maxillary bone, after reflecting a cheek flap. This was done by an incision extending through the upper lip in the middle line passing round the ala ot the nose up to within about half an inch of the inner canthus, and thence passing outwards to the malar prominence. There was free bleeding for a moment while the cheek flap was being dissected up, but this was arrested by firm pressure. After separating the attachments of the bone by means of bone forceps, the bone was found to be so much thinned that it was impossible to get firm hold of it with a pair of lion forceps. It was easily removed piecemeal with a pair of parrot-bill forceps. It was found necessary to remove almost the whole of the floor of the orbit, as the new growth was attached to its under surface. The cavity was firmly plugged with dry lint and iodoform, and the edges of the wound brought into apposition by sutures. No dressing was applied except a piece of lint soaked in ice-cold water. The whole external wound healed by first intention. Patient's temperature never rose above $100^{\circ}$. She left the hospital on June 19 th with a strip of lint lightly plugged into the cavity. By the middle of August she was able to wear a set of artificial teeth, the plate of which completely covered the deficiency of the palate. The scar was almost imperceptible, and no deformity resulted. On July 12th of the present year there was no sign of any recurrence. As the tumour was a myeloid sarcoma, encapsuled and confined to the superior maxilla, the whole bon $\theta$ baving been removed, the chance of its recurrence is not great. Jersey.

\section{TYPHO-MALARIAL FEVER.}

By J. G. LAFFAN, COLONIAL MEDICAL SERTICE.

THERE prevails in the Mediterranean a fever known variously as "Rock," "Levant," "Mediterranean," or "Cyprus" rever, according to the name of the locality in which it occurs. A disease running a similar course is known on the west coast of Africa as "coast" fever, in Western Australia as "colonial," and soldiers are familiar with "Peshawur" fever on the north-west frontier of India. All cases of this fever resemble on $\theta$ another; but, as a rule, they can be divided into classes.

Class 1 -and I have found that the greater number of cases may be placed in this class-contains all those cases in which great fluctuations of temperature, with or without rigors and sweating, are observed, in addition to many of the typical signs of typhoid fever. This class of cases I propose to call " malario-typhoid," as signs of malaria predominate.

In Class 2 I would place all those cases, so common in tropical climates, in which are found nearly all the signs of typhoid (the rash is generally absent), but in which abnormalities occur pointing more or less to the presence of malaria. To such cases the term "typho-malarial" soems peculiarly appropriate.

The differential diagnosis of these two varieties is difficult during the first week of the attack. At the end of that time, in most cases of Class 1, the tongue, which had been, hard and dry, brown-furred and red-edged, becomes moist and clean; if diarrhoea has been present (and it generally is) it ceases, or changes from its typhoid character, the patient's mind becomes clear, and he convalesces; but generally slowly, the temperature remaining high, sometimes for weeks, and most likely one or more relapses will take place. On the other hand, cases of Class 2 run on a course more or less nearly resembling ordinary typhoid fever. Surgeon James, of H.M.S. Téméraire (to whom I take the liberty of referring), has, I believe, in his possession notes and temperature charts of several cases of Class 1 .

The treatment $I$ have adopted in this fever or these fevers has been, for the first week or so, expectant and sustaining afterwards being guided by the symptoms, adopting a course based upon the diagnosis of the nature of the poison present. I am happy to be able to add that up to the present I have been successful.

Wyndham, Cambridge (iulf, Western Australia.

\section{THE FORCEPS IN MIDWIFERY CASES, WITH COILS} OF FUNIS AROUND NECK OF FETUS; ALSO IN PUERPERAL CONVULSIONS.

By T. OsBonNR-WA LKER, M.R.C.S.

QurTe recently I have had under my care four cases of lingering labour, presenting a singular coincidence of symptoms and attendant circumstances, as infrequent, irregular, and inefficient pains, with retrocession of foetal head on subsidence of pain - the presentation being occipito-anterior vertical in all the cases. Three out of the four I delivered with Sir James Simpson'slong forceps and one with Dr. Greenhalgh's short forceps, though I experienced difficulty with the short forceps in consequence of the high position of the head, not having any long forceps with me at the time. Of the four cases the last happened to be the most difficult, as the head of the fotus receded almost beyond touch of the examining finger after cessation of pain, witbout introduction of the hand into the vagina; and this occurred to a multiparous woman, who had borne twins in her immediately preceding confinement. Two of the cases were primiparous and two were multiparous, and in all the funes were convoluted tightly around the necks of the children; and both mothers and infants-though two of the latter were greatly asphyxiated at birth, requiring vigorous application of resuscitative means to revive them-have since progressed most satisfactorily. In two cases of puerperal convulsions I have also applied the forceps with marked success, the convulsions ceasing and consciousness returning immediately on delivery of the fœtal head, mothers and infants alike surviving and doing well. In my early practice days I had a case under my care with the cord tightly applied in two convolutions around the child's neck, necessitating its division to safely complete the birth; and in a subsequent case there were not only two tight coils encircling the neck of the foetus, but both clenched fist $s$ were compressing the cord externally, partially overlapping the horizontal ramus of the lower jaw, and a foot interposed, also external to the funis. This state of things I rectified, and the infant, born limp, pale, and apparently lifeless, I was enabled to resuscitate. Crick.

\section{d a}

\section{HOSPITAL PRACTICE, BRITISH AND FOREIGN.}

Nulla autem est alia pro certo noscendi via, nisi quamplurimas et morborum et dissectionum historias, tum aliorum tum proprias collectas habere, et inter se comparare.-Mongagni De Sed. et Caus. Morb́., lib. iv. Procemium.

WESTMINSTER HOSPITAL.

CASE ILLUSTRATING THE VALUE OF THE INDUCTION BALANCE FOR DETECTING A NEEDLE IN THE THUMB.

(Under the care of Mr. RICHARD DAVY.)

THE use of the induction balance and telephone, as applied in the case recorded, was undoubtedly of the greatest value in proving the presence and localising the position of the foreign body. The publication of this case will again bring before the profession the value of its use in those obscure injuries in which foreign bodies of a metallic character are lodged, when other definite indication of their presence is absent. For proof of the lodgment of bullets, slugs, \&c., at the time of their infliction, the military surgeon has to trust to the evidence obtained by examination of the part, \&c., and cannot utilise such a delicate instrument as that described by Mr. Hawksley. In cases, however, where the missile has been lodged for some time and search with the ordinary instruments has failed, it will doubtless be more employed 